\title{
$\underline{\mathrm{O} J \mathrm{ED}}$
}

Volume 5, Issue 1 (2020), pp. 130-135

International Journal of

Multidisciplinary Perspectives in Higher Education

ISSN: 2474-2546 Print/ ISSN: 2474-2554 Online

https://ojed.org/jimphe

\section{The Covid-19 Crisis and Academic Development: Reflections on Running a Staff Development Webinar Series for Politics/IR Academics}

\author{
Donna Smith \\ The Open University, UK
}

\begin{abstract}
As Co-Chair of the UK Political Studies Association Teaching and Learning Network, the author worked on a webinar series for Politics and IR academics on teaching and learning online. The aim was to meet the development needs of academics suddenly tasked with moving into online teaching due to Covid-19, thus addressing the teaching and learning needs of students at the same time. This Brief essay highlights the key learning points.
\end{abstract}

Keywords: Covid-19, IR, politics, online teaching, staff development, webinars.

The 2020 Covid-19 pandemic tasked many Politics and IR academics across the world with moving from traditional face-to-face campus teaching to a fully online or blended model (often characterised in this context as limited in-person teaching supplemented by online provision). Many academics had never taught online before and were expected to do so with little training (Times Higher Education, 2020a). The UK Political Studies Association (PSA) Teaching and Learning Network was well-placed to support Politics/IR academics within and outside the PSA membership; the author, Co-Chair of the Network, works for one of the world's most well-known online and distance universities, The Open 
University. As such, a series of webinars was developed by the Network focusing on key issues in designing and delivering teaching and learning online. The webinars were held in Zoom and offered to all PSA members, sister learned societies/organisations, and the wider academic community. This Brief essay highlights: 1) the development needs of Politics/IR academics as recognised by the webinar series, 2) the key teaching and learning needs of students identified by the series, and 3) the issues to consider when running a staff development focused webinar series for academics. While the article focuses on Politics/IR, the broader lessons learnt are applicable to other disciplines.

\section{The development needs of politics/IR academics}

The webinar series focused on the following topics: 1) the support needs of academics; 2) the support needs of students; 3) what campus universities can learn from online ones; 4) scaffolding learning/academic communities; and 5) synchronous/asynchronous teaching. The topics were chosen after listening to members at different events and inviting suggestions by email, and were often preceded by a blog post on the topic to gauge interest/feedback. It was clear that attendees were interested in broad pedagogical and design issues within a Politics/IR context (i.e. how to embed assessment, how to increase engagement in a forum, how to constructively align teaching (Biggs, 2003)), technological considerations (the different kinds of technology available, what tools work in specific contexts), as well as issues to do with support and community (of students as well as each other). In relation to the latter, a survey by Pereira et al. (2019) of 38,000 UK university students suggested that one fifth of students has a diagnosed mental health condition, over $40 \%$ were often or always worried, and half had thoughts about self-harm. The mental health of academics is also a concern, with a recent HEPI (2019) survey suggesting UK HE staff are accessing mental health services at an increasing rate. These topics were therefore essential ones to cover, particularly in the Covid-19 context. It also became apparent from informal feedback that the support and guidance Politics/IR academics received during the switch to online teaching was mixed; some received lots of guidance and development, others were left to get on with it. As such, many colleagues were relying on development/training series put on by learned societies such as the PSA, best practice blog posts, and more experienced and supportive colleagues. Significantly, in September 2020 the UK Government announced a consultation with universities and other interested parties on "the challenges and lessons learned from remote teaching and learning delivery since the start of the coronavirus (COVID-19) pandemic" (Office for Students, 2020). While the main focus is the impact on students, the experiences of academics/teachers is also addressed in the consultation, 
including barriers for staff engagement with teaching and learning. The needs of teaching staff are clearly a recognised issue across the sector.

\section{The teaching and learning needs of students}

The webinars elucidated that many colleagues understood the technology and had read the pedagogy, but were still unsure how to make it work for students in practice. Key concerns included: 1) how to improve student engagement online, 2) supporting the emotional/mental health needs of students, and 3 ) how to develop student communities. All very pertinent, as university leaders have identified student interaction and community as a key concern in the switch to online teaching (Times Higher Education, 2020b). It became clear that central to all of these issues is to think less about the technology available and more about what students need, the purpose of the activity they are engaging in (constructive alignment of learning activity and learning outcome (Biggs, 2003)), and how to guide them through their learning. The 'scaffolding' of learning (Maybin et al, 1992), was thus identified as crucial with communication key (between tutors and students, students and students, and in clearly explaining the task at hand), as was providing spaces for the 'non-academic' (both 'social' spaces/engagement, and 'skills'). Essentially, creating a learning environment that works for the students in an online or blended context, rather than trying to replicate a face-to-face learning environment online; thinking about how students actually engage online, what they need, what they will actually use, and what can be done online than can't in other ways (Graham, McNeil and Pettiford, 2017).

\section{Issues to consider when running webinars}

It became clear to the PSA Teaching and Learning Network that many Politics/IR academics were searching for guidance and development on online teaching in the face of Covid-19; particularly as it looks likely that an online or blended HE model may continue, at least partially, in the 20/21 academic year (Guardian, 2020). The PSA could provide the development that some universities could not, at least at such short notice; undoubtedly, such webinar series are an opportunity to raise the profile not only of the issues at hand, but also the learned society/organisation running them, something organisations more generally can take on board when planning outreach. By offering certificates of participation to PSA members who attended at least three webinars, we also tapped into the need many academics have to evidence participation in staff development, which in itself may encourage people to join the organisation (potentially another institutional and financial benefit). Learned societies considering running staff development webinars need to identify the key issues at hand, ideally by surveying members, formally or informally (the latter may be necessary in a crisis situation like Covid-19); by doing so the topics delivered are as 
valuable as possible. The PSA preceded many of the webinars with blogs, often written by the same academics who delivered the webinars; we were therefore able to 'test the water' in terms of subject matter as well as build up a community of practice. We also recorded the sessions, recognising that some members would not be able to attend synchronously, due to work, family, or other demands; issues of equality and diversity should thus be considered when designing a webinar series. We also decided to open up the webinars to non-members, partly as we felt it was important to reach as many academics as possible at such a difficult time, but also in recognition of the importance of community and collegiality. A key lesson learnt, therefore, is that webinar series like this can themselves be a form of discipline-based best practice, as well as an opportunity to reach a wider audience, with the institutional benefits that potentially brings.

\section{Conclusions/ implications}

We had over 350 attendees across the webinar series. ${ }^{8}$ While a UK based learned society, we reached academics across the world. The series would not have been possible without the volunteer presenters, the administrative and technological support provided by the main PSA office, and the agreement of sister organisations to advertise the series to their own members. The series was such a success the PSA has joined with the British International Studies Association (BISA) to run a second webinar series on online teaching and module design/production. A third PSA-run series is also planned for the autumn, on more general teaching and learning matters. Organising these sessions took a lot of time, but feedback from attendees suggests the benefits for academics are clear; the benefits to students should follow on from this. The benefits for the PSA will be felt over time.

The webinar series has shown that that there is huge demand for discipline-based development on (online) teaching and learning; the discipline bit is important, as Politics/IR may have different issues than other disciplines (the high level of classroom discussion, issues of placement learning etc). That said, it is clear that many of the issues raised in the series are applicable across academia more generally; the lessons learnt discussed in this article are therefore relevant to other disciplines. In particular:

\footnotetext{
${ }^{8}$ The open-access webinars can be accessed from this link: https://www.psa.ac.uk/resources/multimedia.
} 
- Academics appreciate a safe space to get together to talk about teaching and learning; doing this on a discipline basis may be useful

- There are issues of both technology and pedagogy, with the latter most pressing. Key issues include student engagement, developing student communities, supporting the emotional/mental health needs of students, and equality and diversity

- It became clear that central to all of these issues is to think less about the technology available and more about what students need, the purpose of the activity they are engaging in, and how to guide them through their learning

- The support needs of academics are important, as well as those of students

- Issues of equality and diversity are fundamental, for students and staff.

Acknowledgements: Thank you to the Political Studies Association staff plus Network colleagues, the webinar hosts, and all participants.

\section{References}

Biggs, J. (2003). Aligning teaching for constructive learning. Higher Education Academy. Available online at: http://www.heacademy.ac.uk/resources/detail/resource databa se/id477 aligning teaching for constructing learning (accessed 18/06/20).

Graham, D., McNeil, J. \& Pettiford, L. (2017). Untangled Web: Developing Teaching on the Internet. London: Routledge.

Higher Education Policy Institute (2019). Pressure Vessels: The epidemic of poor mental health among higher education staff. Available online at: https://www.hepi.ac.uk/wpcontent/uploads/2019/05/HEPI-Pressure-Vessels-OccasionalPaper-20.pdf (accessed 18/06/20).

Maybin, J., Mercer, N. \& Stierer, B. (1992). 'Scaffolding': learning in the classroom. In K Norman (Eds.), Thinking Voices: The work of the National Oracy Project (186-195). London: Hodder \& Stoughton.

Office for Students (2020). Digital teaching and learning in English higher education during the coronavirus pandemic: Call for evidence. Available online at: https://www.officeforstudents.org.uk/publications/digitalteaching-and-learning-in-english-higher-education-during-thecoronavirus-pandemic-call-for-evidence/ (accessed 15/09/20). 
Pereira, S., Reay, K., Bottell, J., Walker, L., Dzikiti, C., Platt, C. \& Goodrham, C. (2019). University Student Mental Health Survey 2018. London: The Insight Network. Available online at:

https:/www.theinsightnetwork.co.uk/uncategorized/university -student-mental-health-survey-2018/ (accessed 18/06/20).

The Guardian (2020). 'Students like the flexibility': why online universities are here to stay. Available online at: https://www.theguardian.com/education/2020/may/27/students -like-the-flexibility-why-online-universities-are-here-to-stay (accessed 18/06/20).

Times Higher Education (2020a). Will the coronavirus make online education go viral? Available online at: https://www.timeshighereducation.com/features/willcoronavirus-make-online-education-go-viral 18/06/20).

Times Higher Education (2020b). Pandemic 'confirms face-to-face teaching is here to stay'. Available online at: https://www.timeshighereducation.com/news/pandemicconfirms-face-face-teaching-here-stay (accessed 18/06/20).

\section{Author Bio}

DONNA SMITH, PhD, is a Politics academic (School of Social Sciences and Global Studies, The Open University), teaching and learning specialist, and experienced manager of Higher Education (CMgr MCMI, Senior Fellow HEA). She is currently Deputy Associate Dean Teaching and Students for The Open University's Faculty of Arts and Social Sciences, and Co-Chair of the Political Studies Association Teaching and Learning Network. Before this, she worked in Westminster Politics. Email: donna.smith@open.ac.uk. 